\title{
Russisk statsopbygning
}

\section{Anna Libak}

Geir Hønneland og Jørgen Holten Jørgensen: Moderne russisk politik - en indføring i Ruslands politiske system. Forlaget Samfundslitteratur, København 2007, 168 s.

De fleste mennesker er klar over, at præsident Putin i sin otteårige regeringstid har gennemført en gevaldig masse reformer af statsapparatet både på føderalt og regionalt niveau. Man kan måske vagt huske, at guvernørerne og præsidenterne for Ruslands 89 subjekter ikke længere sidder i parlamentets overhus Føderationsrådet, men hvem var det nu der erstattede dem? Og hvordan var det egentligt det gik til, at det russiske underhus, Dumaen, gik fra at være en obsternasig, overvejende rødbrun forsamling under Jeltsin og til at være et lydigt og dydigt instrument, der kappes om at klappe højst under Putin?

Svaret kan man finde i en let læst introduktion til moderne russisk politik, skrevet af to forskere ved Fridtjof Nansen-instituttet - dr.polit. og leder af Ruslands- og nordområdeprogrammet Geir Hønneland samt cand.polit. Jørgen Holten Jørgensen. Den kom sidste år i Norge og er nu oversat til dansk. Bogen rummer en faktuel gennemgang af forholdet mellem de øverste statsorganer, organiseringen af statsadministrationen samt forholdet mellem de føderale og regionale myndigheder; det sidste eksemplificeret i tre særskilte kapitler om russisk miljøbeskyttelse, fiskeriforvaltning og råstofudvinding, der hører til Fritjof Nansen-instituttets forskningsområder.

Endelig er der et overordnet kapitel om mediernes og civilsamfundets rolle. Hvert enkelt kapitel indledes med en gennemgang af den institutionelle opbygning af området i sovjettiden og følger udviklingen over Jeltsin og videre til Putin. Det er perspektivrigt: For det er lettere at forstå, hvordan præsidentadministrationen kunne blive så magtfuld, når man har det sovjetiske politbureau in mente.

Bogen er hurtigt læst og kan absolut anbefales - særlig i den kommende tid, hvor Rusland vil stå højt på nyhedsmediernes dagsorden i forbindelse med det forestående valg til det russiske underhus Dumaen den 2. december 2007 og præsidentvalget den 9. marts 2008 . 